\title{
Low Salinity Facilitates the Replication of Infectious Myonecrosis Virus and Viral Co-Infection in the Shrimp Litopenaeus Vannamei
}

\author{
P. R. N. Vieira-Girão", I. R. C. B. Rocha ${ }^{2,3}$, M. Gazzieno², P. R. N. Vieira ${ }^{1}$, H. M. R. Lucena ${ }^{4}$, F. H. F. Costa ${ }^{2}$ and G. Rádis-Baptista ${ }^{1 *}$ \\ ${ }^{1}$ Laboratory of Biochemsitry and Biotechnology, Institute for Marine Sciences, Federal University of Ceará. Fortaleza, Ceará, Brazil \\ ${ }^{2}$ Department of Fish Engineering, Federal University of Ceará, Fortaleza, Ceará, Brazil \\ ${ }^{3}$ Compescal Fishery Company Ltd., Aracati, Ceará, Brazil \\ ${ }^{4}$ Federal Institute for Education, Science and Technology, Ceará, Brazil
}

\begin{abstract}
The white leg shrimp Litopenaeus vannamei has been converted commercially into the most predominant cultivated shrimp species in the world. However, such shrimp's intensive farming worldwide propitiates outbreaks of epizootic diseases, primarily of viral etiology. In the principal Brazilian region of shrimp production, it is known that a reduction in the salinities of culture ponds causes the appearance of viral diseases. In the present work, we investigate the replication of the infection myonecrosis virus (IMNV) in controlled levels of salinity during the first 12 hours of infection. Using quantitative real-time PCR and statistical analysis, we verify that low salinity positively facilitates IMNV replication and proliferation by decreasing the generation time from 57.4 min (at $35 \mathrm{~g} \mathrm{~L}^{-1}$, optimum salinity) to 25.2 min at ( $5 \mathrm{~g} \mathrm{~L}^{-1}$, stressing concentration). Similarly, a positive relationship was demonstrated between a decrease in salinity and the reduction in the generation time of persistent infectious hypodermal and hematopoietic necrosis virus, a virus that usually co-infects shrimp in farm ponds.
\end{abstract}

Keywords: L. Vannamei; Shrimp virus; IMNV; Qpcr; Epizootic agent; Viral replication; Generation time

\section{Introduction}

The white leg shrimp Litopenaeus vannamei is naturally found along the Pacific coast from the Golf of California to the north littoral of Peru [1]. Due to the rearing performance in shrimp farming, L. vannamei has been converted into the most predominant cultivated shrimp species in the world, reaching approximately 2.7 million cubic tons and over 10 billion dollars in sales in the year of 2010 [2]. The characteristics that make this species of shrimp adequate for commercial production, particularly in the Americas, include fast growth, low nutritional requirements, resistance to environmental stress, and a certain osmoregulatory capability for adaptation to a wide range of salinity (from 1 to $50 \mathrm{~g} \mathrm{~L}^{-1}$ ) [3]. The intensive rearing techniques required for efficient and cost-effective shrimp farming unintentionally propitiate the outbreaks of epizootic diseases, and severe microbial infection is consequently a recurrent threat in the shrimp industry. Some of the most serious causative infectious agents in shrimp aquaculture are viruses. The northeastern part of Brazil is the most productive region with a total of 18,500 hectares of shrimp farms that account for approximately 70,000 tons of shrimp, which corresponds to $97 \%$ of the national production $[4,5]$. In this region, two main types of viruses are of great concern: the infection myonecrosis virus (IMNV) and the infectious hypodermal and hematopoietic necrosis virus (IHHNV). Based on their genome organization, the phylogeny of their macromolecular components, the structural characteristics of their capsids and the physical-chemical properties of the viral particles, the first is classified as a member of the Totiviridae family [6,7], and the latter belongs to the Parvoviridae family [8]. As a virus of the Totiviridae family, IMNV is double-stranded RNA virus deprived of an envelope with an isometric capsomer and a genome size of 7560 base pairs encoding two nonoverlapping open reading frames (ORFs), which comprise a predicted RNA-binding protein and a capsid protein [7]. In contrast, IHHNV is a non-enveloped, symmetric icosahedral parvovirus with a singlestranded linear DNA genome composed of 3909 nucleotides and three superposed ORFs $[8,9]$. When infecting penaeid shrimps, IMNV causes high mortality rates by acutely destroying (via necrosis) the skeletal muscle of distal segments and the tail fan. In contrast, IHHNV causes chronic deformity syndrome and reduced growth and culture performance [10]. In both cases, environmental factors, such as salinity and temperature, appear to trigger viral outbreaks in shrimp culture.

In a previous survey, after an unusual period of rainfall resulting in high mortality and significant economic losses in local shrimp production, we used molecular procedure analysis to find that a high number of samples from extensively farmed $L$. vannamei developing IHHN or IMN disease were co-infected with both (IHHNV and IMNV) viral agents [11]. In addition, we have shown that the disease symptoms and outcomes found for the co-infected shrimps resulted from reciprocal viral replication, i.e., the proliferation of one type of virus impairs the multiplication of the other. In the same study, we observed that IHHNV appeared to modulate the expression of heat shock protein 70 (HSP70) in IHHNV/IMNV double-infected shrimp.

In aquatic organisms, particularly shrimps, the oscillation provoked by physical (e.g., temperature), chemical (pesticides, $\mathrm{pH}$ and salinity) and biological (epibionts, epizootics, enzootics, etc.) insults, which are part of the equivocal strategies of farming management, may independently or cooperatively work to cause outbreaks of severe infections and mortality [12-16]. Moreover, a direct relation between environmental stress, immunity imbalance and development of bacterial and viral infection and disease has been observed at molecular and organism level in shrimp $[17,18]$.

*Corresponding author: Radis-Baptista G, Laboratory of Biochemsitry and Biotechnology, Institute for Marine Sciences, Federal University of Ceará Fortaleza, Ceará, Brazil, Tel: 002-055-228-3683; E-mail: gandhi.radis@ufc.br

Received November 19, 2014; Accepted December 10, 2014; Published January 12, 2015

Citation: Vieira-Girão PRN, Rocha IRCB, Gazzieno M, Vieira PRN, Lucena HMR et al. (2014) Low Salinity Facilitates the Replication of Infectious Myonecrosis Virus and Viral Co-Infection in the Shrimp Litopenaeus Vannamei. J Aquac Res Development 6: 302. doi:10.4172/2155-9546.1000302

Copyright: () 2015 Vieira-Girão PRN, et al. This is an open-access article distributed under the terms of the Creative Commons Attribution License, which permits unrestricted use, distribution, and reproduction in any medium, provided the original author and source are credited. 
Citation: Vieira-Girão PRN, Rocha IRCB, Gazzieno M, Vieira PRN, Lucena HMR, et al. (2015) Low Salinity Facilitates the Replication of Infectious Myonecrosis Virus and Viral Co-Infection in the Shrimp Litopenaeus Vannamei. J Aquac Res Development 6: 302. doi: $10.4172 / 2155-9546.1000302$

The aim of the present work was to investigate, in controlled laboratory conditions, the influence of low salinity on the replication of IMNV in L. vannamei. Additionally, we monitored the proliferation of IHHNV and estimated the generation time $(\mathrm{g})$ of replication for both viruses under the influence of different salinities.

\section{Material and Methods}

\section{Shrimp maintenance and experimental viral infection}

A total of 150 macroscopically healthy shrimps were obtained from a local shrimp farm (Paraípaba, Ceará - CE, Brazil) and transported to the Laboratory of Aquatic Resources of the Federal University of Ceará (CE-Brazil). The shrimps were acclimated for one week in a $1000-\mathrm{L}$ tank filled with seawater, the salinity of which was similar to that in the collection site $\left(35 \mathrm{~g} \mathrm{~L}^{-1}\right)$ and controlled through a flow-through system. The shrimp were fed ad libitum a commercial diet $(35 \%$ crude protein; Nutreco Fri-Ribe ${ }^{\oplus}$, Ceará, Brazil). After acclimation, the shrimps $(9.3 \pm 1.2 \mathrm{~g})$ were captured, anaesthetized with $100 \mathrm{mg}$ $\mathrm{L}^{-1}$ benzocaine, randomly selected, weighed, counted and stocked into 30-L aquaria (10 shrimp per aquarium) with three replicate aquaria for each treatment. The experimental procedure was conducted with four different salinities, yielding a control group $\left(35 \mathrm{~g} \mathrm{~L}^{-1}\right)$ and four treatments $\left(5,15,25\right.$ and $\left.35 \mathrm{~g} \mathrm{~L}^{-1}\right)$. Each treatment was operated on a common recirculation system with $200-\mathrm{L}$ mechanical and biological filters and a water exchange of approximately $0.5 \mathrm{~L} \mathrm{~min}^{-1}$ per aquarium. Each aquarium was equipped with an air diffuser to maintain an oxygen concentration in the water close to saturation. Nets to prevent the shrimp from jumping out covered each aquarium. The salinity was gradually reduced by pumping disinfected freshwater at a rate of 0 (control and treatment 1) or $2 \mathrm{~g} \mathrm{~L}^{-1}$ (treatments 2, 3 and 4) per hour until reaching the salinity corresponding to each treatment. The salinity levels were monitored using an optical refractometer. The water in the aquaria were maintained at ambient temperature within a range of 27.5 to $30.5^{\circ} \mathrm{C}$ and a mean temperature of $29.0^{\circ} \mathrm{C}$ during the experimental period. The temperature differences among the aquaria never exceeded $0.2^{\circ} \mathrm{C}$. A photoperiod of $12 \mathrm{~h}$ of light (L)/12 h of darkness (D) was maintained during the experiment.

The IMNV inoculum was obtained from the muscle of IMNVinfected shrimp collected during a disease outbreak that occurred in a shrimp cultivation pond in 2011 . For viral extract preparation, the muscle from infected shrimp (L. vannamei) was homogenized in PBS (0.2 M phosphate buffered saline, pH 7.3) (1:3, w/v). The shrimp extract was centrifuged at $3000 \times \mathrm{g}$ for $5 \mathrm{~min}$, and the supernatant was used for viral inoculation into healthy shrimps. The concentration of the IMNV stock was quantified by real-time PCR and found to be a target copy number of $10^{4}$ per microliter. For the shrimp challenges, $10 \mu \mathrm{l}$ of the viral suspension was injected into each shrimp. The shrimp in the negative control group were injected with the same volume of phosphate buffered-saline.

\section{Shrimp tissue processing and total RNA purification}

The hepatopancreas from three shrimps in each group was dissected at $0,1.5,3,6$ and 12 hours post-injection and transferred to microtubes containing RNA Later solution (Life Technologies, CA, USA) for total RNA purification. The samples were maintained at $4^{\circ} \mathrm{C}$ until processing, and the total RNA was purified within one week following collection. The inoculated shrimps were observed from 0 to $48 \mathrm{~h}$ post infection for clinical signs of IMN disease, such as anorexia, lethargy and mortality.

The total RNA from the minced hepatopancreas (20 to $30 \mathrm{mg}$ ) was extracted using the SV Total RNA Isolation System (Promega, Madison, WI, USA), according to the manufacturer's protocol, which includes a DNase I treatment step. The quality and yield of the total RNA were verified by assessing the integrity of $28 \mathrm{~S}$ and $18 \mathrm{~S}$ rRNA and by spectrometrically assessing the $260 / 280 \mathrm{~nm}$ ratio.

\section{cDNA synthesis from viral RNA}

For complementary DNA (cDNA) synthesis, up to $1 \mu \mathrm{g}$ of each DNase I-treated total RNA sample, which was mixed with $500 \mathrm{ng}$ of random primers (Promega, Madison, WI, USA) in a final volume of $10 \mu \mathrm{l}$, was heated to $70^{\circ} \mathrm{C}$ for $10 \mathrm{~min}$ and cooled at $4^{\circ} \mathrm{C}$. To complete the reverse transcriptase reaction mixture, the following components were mixed with the denatured RNA in a final volume of $20 \mu \mathrm{l}: 100 \mathrm{U}$ of ImProm II reverse transcriptase enzyme (Promega, Madison, WI, USA), $1 \mathrm{mM}$ of each deoxynucleoside triphosphate, $2 \mathrm{mM} \mathrm{MgSO}_{4}, 1 \mathrm{mM}$ dithiothreitol, and $20 \mathrm{U}$ of RNase inhibitor. The reverse transcription mixture was incubated at $42^{\circ} \mathrm{C}$ for $90 \mathrm{~min}$ and then at $70^{\circ} \mathrm{C}$ for $15 \mathrm{~min}$. The cDNA was diluted tenfold with TE $(10 \mathrm{mM}$ Tris- $\mathrm{HCl}, \mathrm{pH} 7.5,1$ $\mathrm{mM}$ ethylenediaminetetraacetic acid), and $2-\mu \mathrm{l}$ aliquots were used for the relative and quantitative real-time PCR (qPCR) experiments.

\section{Quantitative real-time PCR of shrimp virus (IMNV and IHHNV)}

For the quantification of the IHHNV and IMNV loads in $L$. vannamei, the absolute quantitative strategy was used. The genes encoding the nonstructural proteins of IMNV (GenBank accession number AAT67231.1) and of IHHNV (GenBank accession number AAF59415.1) were cloned, and serial 10-fold dilutions of each gene were prepared to establish the qPCR standard curves. The standard curve series were constructed in triplicate. The linearity of the qPCR standard curve was expressed as the square of the Pearson correlation coefficient $\left(r^{2}\right)$. The primers for the qPCR detection of IMNV and IHHNV, in addition to those used for the shrimp $\beta$-actin gene, are detailed elsewhere [11].

The amplification of all cDNAs in this study was conducted in a Rotor-Gene 3000 system operated with its respective software (version 6.0.19; Corbett Research, Mortlake, Australia). Each reaction, which was conducted in a final reaction volume of $20 \mu \mathrm{l}$, consisted of 2.0 $\mu \mathrm{l}$ of the cDNA ( $10 \mathrm{ng}$ of reverse-transcribed mRNA), $0.2 \mu \mathrm{M}$ of each gene specific sense and anti-sense primer, and $10 \mu \mathrm{l}$ of two-fold concentrated GoTaq qPCR Master Mix (Promega, Madison, WI, USA). The amplification conditions for the viruses were as follows: 35 cycles of $95^{\circ} \mathrm{C}$ for $30 \mathrm{~s}, 55^{\circ} \mathrm{C}$ for $30 \mathrm{~s}$, and $72^{\circ} \mathrm{C}$ for $30 \mathrm{~s}$. The fluorescence was collected at 494 to $521 \mathrm{~nm}$ during the extension phase.

To calculate the copy number in the absolute qPCR experiments, the following equation was used (http://www.uri.edu/research/ gsc/resources/cndna.html): Number of copies=[DNA amount (ng) $\left.{ }^{*} 6.022 \times 10^{23}\right] /\left[\right.$ DNA length $\left.(\mathrm{nt})^{*} 1 \times 10^{9}{ }^{*} 650\right]$. The threshold and threshold cycle values were automatically determined by the Rotor Gene 6.0.19 software using the default parameters. All of the measurements were obtained as the means of at least nine measurements \pm SEM (less than $5 \%$ error). The corresponding real-time PCR efficiencies (E) of the cycles in the exponential phase were calculated from the given slopes (k) according to the following equation: $\mathrm{E}=10^{(-1 / \mathrm{k})}-1$. To normalize the values of the viral load, the mean copy number of $\beta$-actin transcripts in each sample, which is equivalent to $1 \mu \mathrm{g}$, was determined from at least ten independent experiments $(n \geq 30)$; the results of the viral infection and gene expression analyses are denoted as the logarithm of the copy number. 
Citation: Vieira-Girão PRN, Rocha IRCB, Gazzieno M, Vieira PRN, Lucena HMR, et al. (2015) Low Salinity Facilitates the Replication of Infectious Myonecrosis Virus and Viral Co-Infection in the Shrimp Litopenaeus Vannamei. J Aquac Res Development 6: 302. doi: 10.4172/2155-9546.1000302

Page 3 of 6

\section{Statistical analysis}

The statistical analyses were performed with the BioStat 5.0 software using one-way ANOVA. In the cases in which significant differences were observed, the Least Significant Differences (LSD) test was applied. The positive correlation between the viral loads was expressed as the Pearson coefficient (r).

\section{Results and Discussion}

In a recent study, we assessed the expression level of selected gene transcripts (i.e., crustin, peneidin-3a, C-type lectin and HSP70) related to the innate immune systems of shrimp in response to viral infection caused by IMNV and IHHNV after an unusual period of rainfall in a delimited shrimp production area [11]. Under the natural conditions of shrimp culture, we detected that a high proportion of shrimp samples were positive for both viruses, i.e., they were environmentally co-infected with IMNV and IHHNV. Interestingly, a phenomenon of reciprocal viral replication appeared to occur in this type of coinfection: the species of virus and the viral load at the beginning of the infection determined the disease outcome, i.e., IMN or IHHN disease in the shrimp. Moreover, the level of HSP70, which is a cytoprotective protein, was up-regulated by viral infection and displayed a positive correlation with IHHNV replication. However, these data were obtained from shrimps sampled under natural culture conditions, in which some parameters, such as salinity, temperature and exposition to a complex microbiota (and potential pathogens), were not subjected to a strict control. Therefore, we were compelled to conduct a controlled set of experiments on virus replication in shrimp as a function of different salinities to verify the correlation between salt stress and viral proliferation.

With this aim, a total of 150 asymptomatic adult shrimps were acclimatized in the laboratory to different levels of salinity $(5,15,25$ and $35 \mathrm{~g} \mathrm{~L}^{-1}$ ) and intramuscularly inoculated with 100,000 IMNV particles $\left(10^{4} / \mu \mathrm{L}\right)$. Samples of the hepatopancreas were surgically collected from three individual shrimps $0,1.5,3,6$ and $12 \mathrm{~h}$ post-infection, and the level of viral replication was assessed by qPCR. From the same samples, the number of copies of IHHNV and the number of transcripts of crustacean $\beta$-actin were determined. As might be expected, the number of IMNV particles increased steeply in all salinities tested (Figure 1, part A). Unexpectedly, IHHNV was also detected just after the beginning of the experiment and thereafter, even though the only virus that was deliberately inoculated in the study was IMNV (Figure 1B). This finding reflects the nature of IHHNV as a persistent epizootic agent that is present in all stages of the shrimp life cycle, including larvae and asymptomatic adults, and that is capable of invading the germ line and integrating into the host genome. Interestingly, in the first hours post-inoculation (between $1.5 \mathrm{~h}$ and $3 \mathrm{~h}$ ), the high number of IMNV particles suppressed the replication of IHHNV, as observed in Figure 1, in agreement with one of our previous studies. In the subsequent period of infection, IHHNV also proliferated gradually over, particularly at a salinity of $5 \mathrm{~g} \mathrm{~L}^{-1}$, whereas IMNV replicated exponentially over time and in lower salinities. At a salinity of $35 \mathrm{~g}$ $\mathrm{L}^{-1}$, the estimated generation times for IHHNV and IMNV were 37.2 min and $57.4 \mathrm{~min}$, respectively, in contrast to the values of $17.1 \mathrm{~min}$ and $25.2 \mathrm{~min}$ found at $5 \mathrm{~g} \mathrm{~L}^{-1}$, respectively. This estimation, which was obtained through the calculation of the viral copy number as a function of the time post-infection, clearly indicates that the generation time for both viruses is practically reduced by two-fold when the salinity is decreased from $35 \mathrm{~g} \mathrm{~L}^{-1}$ to $5 \mathrm{~g} \mathrm{~L}^{-1}$. Curiously, these values indicate that the persistent IHHN virus detains a lower generation time than IMNV, but due to the experimental design in the aquarium for IMNV
A

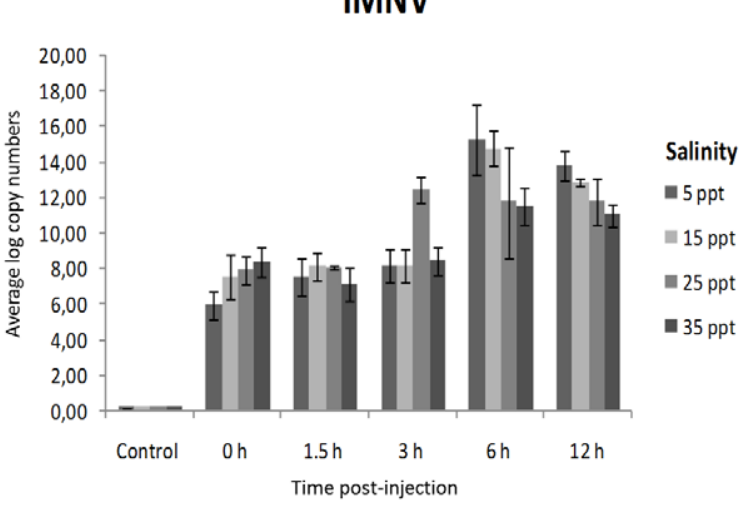

B

IHHNV

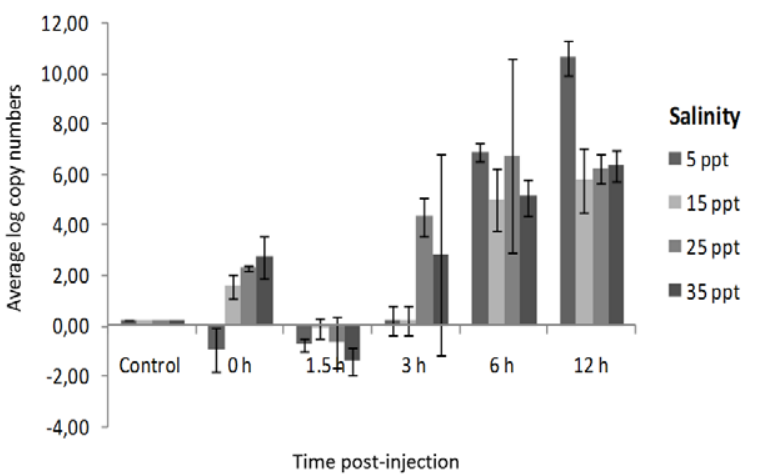

Figure 1: Influence of different salinities on the replication of IMNV and IHHNV in $L$. vannamei. Shrimps were acclimatized in $5,15,25$ and $35 \mathrm{~g} \mathrm{~L}^{-1}$ of salinity and experimentally infected with IMNV. The viral replication was assessed 0 $\mathrm{h}, 1.5 \mathrm{~h}, 3 \mathrm{~h}, 6 \mathrm{~h}$ and $12 \mathrm{~h}$ after virus inoculation (A). The replication of IHHNV was also monitored $(B)$. In each shrimp sample $(n \geq 6)$, the actively transcribed genes from IMNV and IHHNV were quantified by absolute qPCR using cDNA as the template and specific primers. The number of viral particles was then normalized in relation to the logarithm (Log10) of the mean copy number of 1 $\mu \mathrm{g}$ of shrimp $\beta$-actin transcripts.

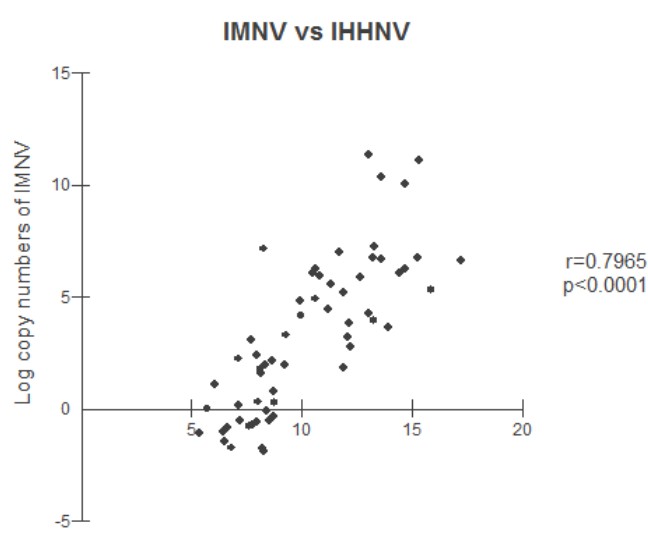

Log copy numbers of IHHNV

Figure 2: Linear correlation between IMNV and IHHNV replication in shrimp Plot (coordinate pairs) of IMNV vs. IHHNV proliferation in different salinities and at different times post-infection. The quantitative PCR data were obtained and statistically analyzed as described in the text. The values of the Pearson coefficient $(r)$ and probability $(p)$ are shown in the plots. 
Citation: Vieira-Girão PRN, Rocha IRCB, Gazzieno M, Vieira PRN, Lucena HMR, et al. (2015) Low Salinity Facilitates the Replication of Infectious Myonecrosis Virus and Viral Co-Infection in the Shrimp Litopenaeus Vannamei. J Aquac Res Development 6: 302. doi: $10.4172 / 2155-9546.1000302$

Page 4 of 6

replication, as well as the phenomena of reciprocal replication that we had previously observed, the fortuitous number of viral copies of IHHNV was constantly inferior to that of IMNV through the experiment. Moreover, as noted, the replication of IMNV occurs in all levels of salinity and periods of time post-infection, by which were experimentally and statistically tested (coefficient of Pearson, $r=79.65 \%)$. The positive correlation between the different salinities and the time of infection for IMNV versus IHHNV was observed with high confidence (Figure 2).

According to our measurements, the peak of IMNV replication reached a maximum in $6 \mathrm{~h}$ after infection, suggesting a rapid and efficient mechanism of cell entry and co-option of the molecular machinery of host cells for viral proliferation. In the earlier period of infection (from $0 \mathrm{~h}$ to $3 \mathrm{~h}$ ), the difference in the virus number relative to the preceding hour was not statistically significant, although we observed an increment in the IMNV copy number (Figure 3).

The decrease in the salinity of shrimp culture ponds during the rainy season and the appearance of viral diseases is a known fact of shrimp producers in the northeastern region of Brazil. The scientific reasoning underlying this phenomenon calls for the influence of the osmotic shock response on the components of the crustacean innate immunity system. Thus, a stress caused by osmotic adjustment may trigger the viral replication and the high shrimp mortality observed in the field.

In fact, the maintenance of the isosmotic level of salinity is required to avoid a reduction in the efficiency of innate immunity responses and an increase in the vulnerability of marine shrimps to epizootic agents
[19]. The isotonic salinity is a key environmental factor influencing the physiology of numerous species of marine organisms, from algae to fishes. In shrimps in particular, abrupt changes in salinity can affect the metabolic efficiency, the consumption of oxygen, and the rates of growth and survival [20]. Li and collaborators observed that shrimps inoculated with Vibrio alginolyticus and maintained under low salinity displayed, after 6 to $12 \mathrm{~h}$, a significant reduction in immune factors, such as the number of hemocytes and prophenoloxidase activity.

The relationship between fluctuations in salinity and the susceptibility of shrimp to virus infection has been increasingly studied in the case of white spot syndrome virus (WSSV). In a study conducted by Vaseeharan and collaborators [20], the influence of low salinity on the innate immune system of healthy Fenneropenaeus indicus challenged with white spot syndrome virus (WSSV) was investigated. These researchers observed a reduction in the shrimp immune competence and an increase in the susceptibility to the virus. In addition, Ramos-Carreño and co-workers studied the susceptibility of L. vannamei to WSSV in several levels of salinities and found that the clinical manifestation of viral infection was more severe in condition of hyposmolarity. The low salinity was also verified to contribute to a decrease in the osmoregulation performance of L. vannamei and an increase in the replication of WSSV, resulting in higher rates of shrimp mortalities [21].

In the same line, our results demonstrate that the replication rate was higher at a lower salinity (i.e., $5 \mathrm{~g} \mathrm{~L}^{-1}$ ) for both viruses, the IMNV and the persistent IHHNV, over a period of 6 to $12 \mathrm{~h}$ of infection
A

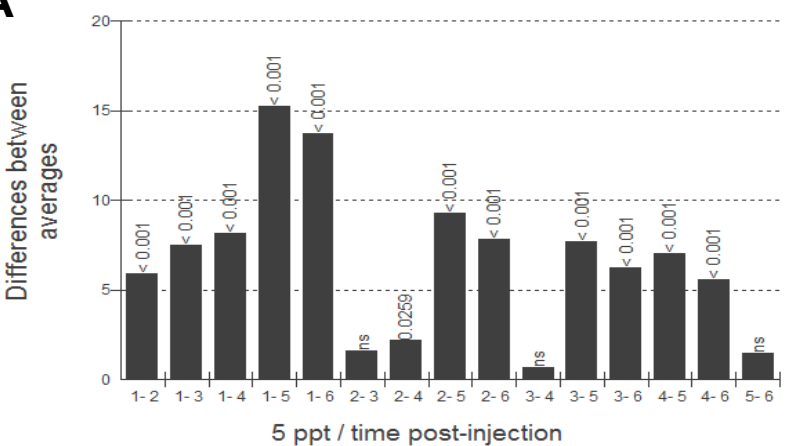

C

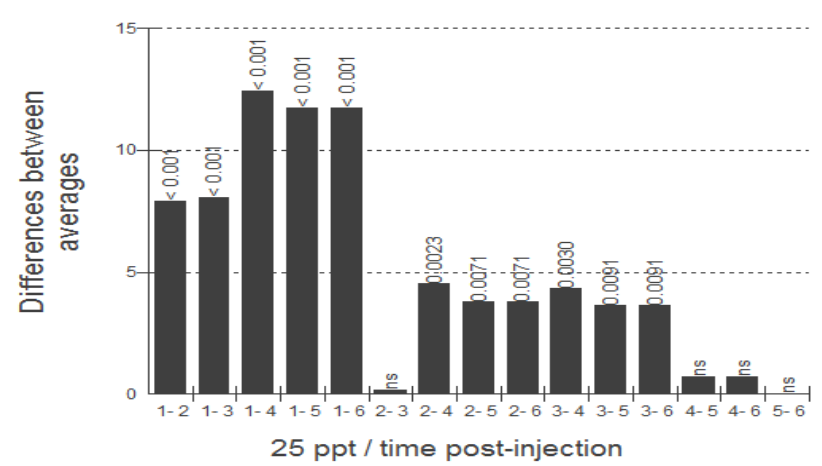

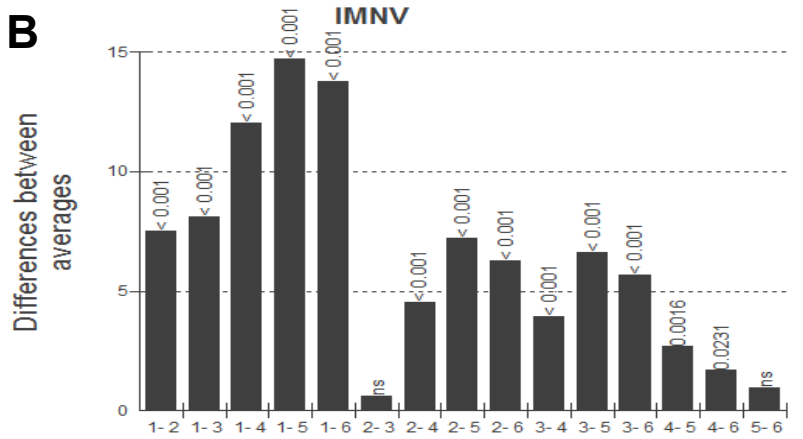

$15 \mathrm{ppt} /$ time post-injection

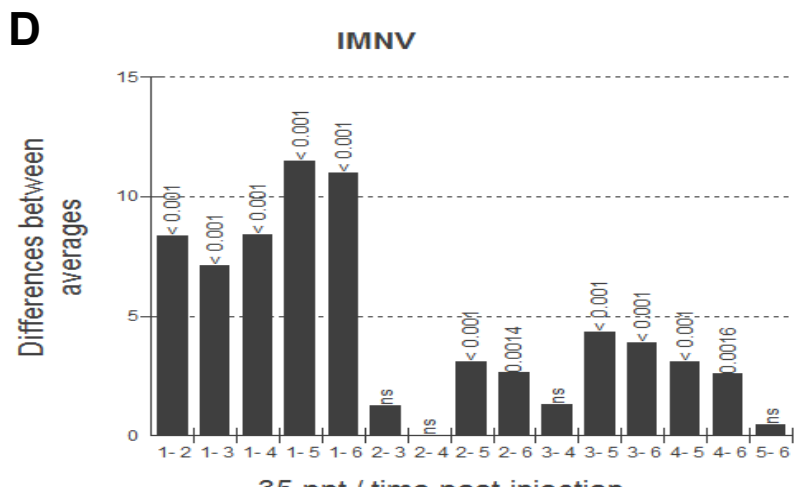

35 ppt / time post-injection

Figure 3: Significant differences in the replication of IMNV in infected shrimp over time. Differences between the logarithm of the mean copy number of IMNV in control

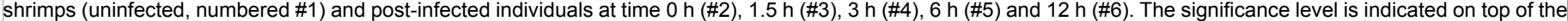
bar. The abbreviation "ns" denotes "no statistically significant difference". 
Citation: Vieira-Girão PRN, Rocha IRCB, Gazzieno M, Vieira PRN, Lucena HMR, et al. (2015) Low Salinity Facilitates the Replication of Infectious Myonecrosis Virus and Viral Co-Infection in the Shrimp Litopenaeus Vannamei. J Aquac Res Development 6: 302. doi: $10.4172 / 2155-9546.1000302$

Page 5 of 6

A

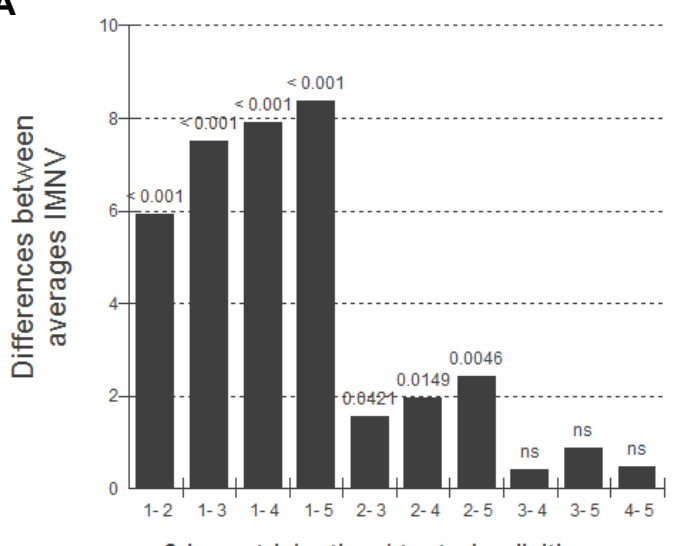

$\mathrm{O}$ h post-injection / tested salinities

B

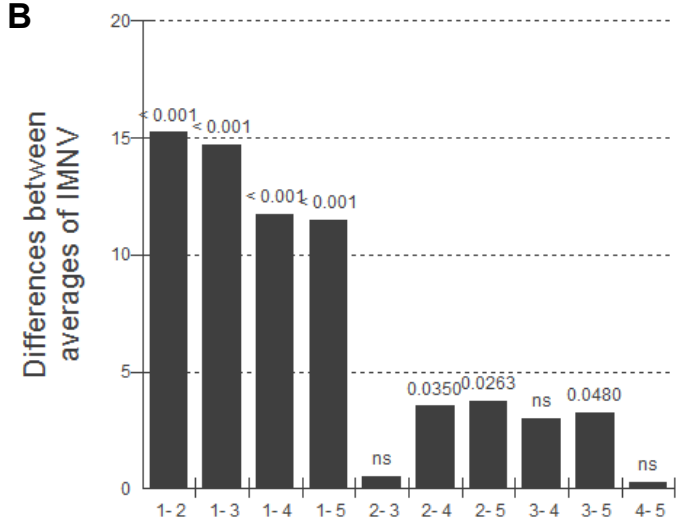

$6 \mathrm{~h}$ post-injection / tested salinities

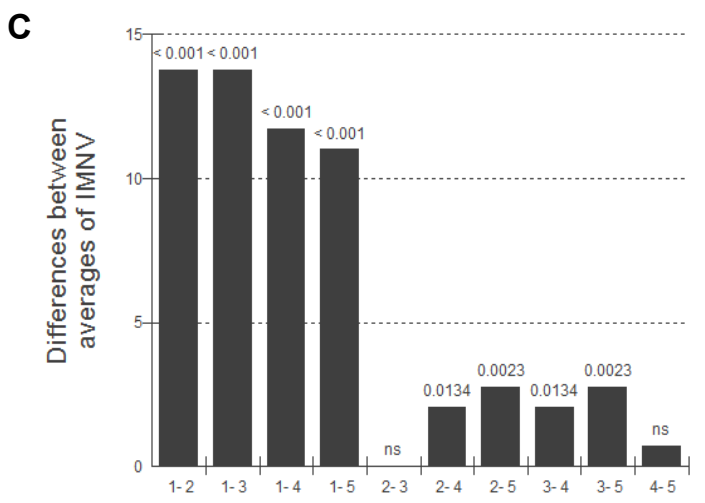

$12 \mathrm{~h}$ post injection / tested salinities

Figure 4: Significant differences in the replication of IMNV in infected shrimp in relation to the salinity and time. Differences between the logarithm of the mean copy number of IMNV in control shrimps acclimated to a salinity of $35 \mathrm{~g}$ $\mathrm{L}^{-1}$ (numbered \#1) and infected individuals at a salinity of $5 \mathrm{~g} \mathrm{~L}^{-1}(\# 2), 15 \mathrm{~g} \mathrm{~L}^{-1}$ (\#3), $25 \mathrm{~g} \mathrm{~L}^{-1}(\# 4)$, or $35 \mathrm{~g} \mathrm{~L}^{-1}$ (\#5) were monitored at time $0 \mathrm{~h}(\mathrm{~A}), 6 \mathrm{~h}(\mathrm{~B})$ and 12 $h(C)$. As mentioned in the legend of figure 3 , the significance level is indicated on top of the bar, and "ns" denotes "no statistically significant difference".

(Figures 4 and 5).

In summary, we focused our analysis primarily on the replication of IMNV in controlled conditions with different salinities and thus controlled osmotic conditions. Using quantitative real-time PCR data and statistical analysis, we verified that low salinity facilitates the replication of infectious myonecrosis virus by decreasing the generation time. In addition, under conditions of fluctuation of salt content in salt water, we observed the same behavior in the proliferation of the persistent IHHN virus, i.e., a decrease in the time for viral duplication and a positive correlation between a low level of salinity and increased

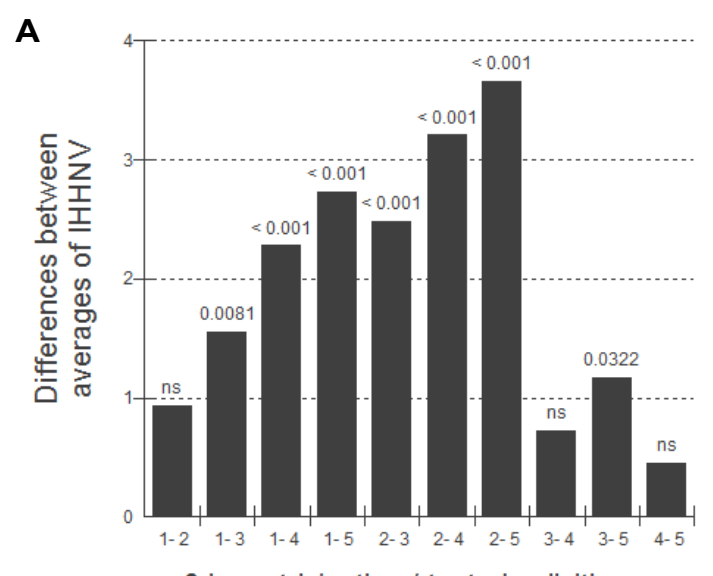

$\mathrm{O}$ h post-injection / tested salinities

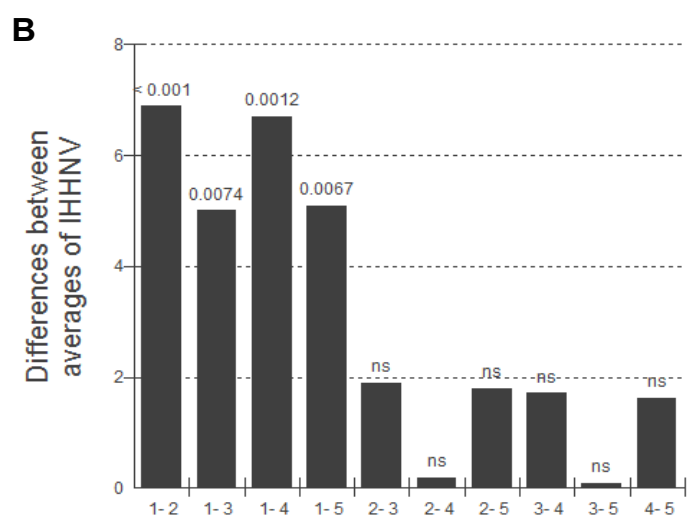

$6 \mathrm{~h}$ post-injection / tested salinities

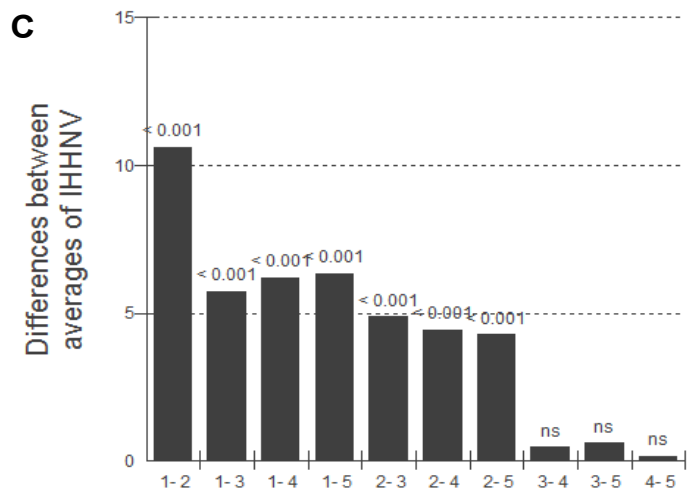

$12 \mathrm{~h}$ post-injection / tested salinities

Figure 5: Significant differences in the replication of IHHNV in infected shrimp in relation to the salinity and time. Differences between the logarithm of the mean copy number of IHHNV in control shrimps at a salinity of $35 \mathrm{~g} \mathrm{~L}^{-1}$ (numbered \#1) and infected individuals adapted to a salinity of $5 \mathrm{~g} \mathrm{~L}^{-1}(\# 2), 15$ $\mathrm{g} \mathrm{L}^{-1}$ (\#3), $25 \mathrm{~g} \mathrm{~L}^{-1}$ (\#4), or $35 \mathrm{~g} \mathrm{~L}^{-1}$ (\#5) were monitored at time $0 \mathrm{~h}(\mathrm{~A}), 6 \mathrm{~h}(\mathrm{~B})$ and $12 \mathrm{~h}(\mathrm{C})$. As mentioned, the significance level is indicated on top of each bar, and "ns" denotes "no statistically significant difference". 
Citation: Vieira-Girão PRN, Rocha IRCB, Gazzieno M, Vieira PRN, Lucena HMR, et al. (2015) Low Salinity Facilitates the Replication of Infectious Myonecrosis Virus and Viral Co-Infection in the Shrimp Litopenaeus Vannamei. J Aquac Res Development 6: 302. doi: $10.4172 / 2155-9546.1000302$

virus multiplication, consequently, facilitating the co-infection in $L$. vannamei.

\section{Acknowledgment}

This research study was supported by the Brazilian National Council for Scientific and Technological Development (CNPq) of the Ministry of Science and Technology (National Program for Animal Health; grant \#578460/08-4). Part of this project was co-sponsored by the strategic actions of the Ministry of Fishery and Aquaculture of the Federal Government of Brazil. P.R.N. Vieira-Girão and I.R.C.B. Rocha are recipients of fellowships from the Coordination for the Improvement of Higher Education Personnel (Coordenação de Aperfeiçoamento de Pessoal de Nivel Superior - CAPES). We thank Dr. Claudio Borges Falcão for discussion on statistical data and determination of viral generation times. G. Rádis-Baptista is a member of the Scientific Committee of CNPq.

\section{References}

1. Perez Farfante I, Kensley B (1997) Penaeoid and sergestoid shrimps and prawns of the world. Keys and diagnoses for the families and genera. Memories du Museum National D'Historie Naturelle, Paris, France.

2. FAO (2012) FAO Fisheries Department, Fishery Information and Statistics Unit. FISHSTAT Plus Version 2.3.2, Database Aquaculture Production 1950-2010. Available at [URL http://www. fao.org/fishery]

3. FAO (2007) FAO Fisheries Department, Fishery Information, Data and Statistics Unit. FISHSTAT Plus Version 2.3.2, Database Aquaculture Production 19502010

4. Rocha IP (2011) Current status and trends in Brazilian shrimp farming. Infofish Intl 5: 24-28

5. Moles P, Bunge J (2002) Shrimp farming in Brazil: An industry overview. In: Report prepared under the World Bank, NACA, WWF and FAO Consortium Program on Shrimp Farming and the Environment.

6. Tang J, Ochoa WF, Sinkovits RS, Poulos BT, Ghabrial SA, et al. (2008) Infectious myonecrosis virus has a totivirus-like, 120-subunit capsid, but with fiber complexes at the fivefold axes. Proc Natl Acad Sci USA 105: 1752617531.

7. Poulos BT, Tang KF, Pantoja CR, Bonami JR, Lightner DV (2006) Purification and characterization of infectious myonecrosis virus of penaeid shrimp. J Gen Virol 87: 987-996.

8. Bonami JR, Trumper B, Mari J, Brehelin M, Lightner DV (1990) Purification and characterization of the infectious hypodermal and haematopoietic necrosis virus of penaeid shrimps. J Gen Virol 71: 2657-2664.
9. Tang KF, Poulos BT, Wang J, Redman RM, Shih HH, Lightner DV (2003) Geographic variations among infectious hypodermal and hematopoietic necrosis virus (IHHNV) isolates and characteristics of their infection. Dis Aquat Organ 53: 91-99.

10. Office international des épizooties (OIE) (2011) Manual of diagnostic tests fo aquatic animals. OIE Aquatic Animal Health Standards Commission, Paris

11. Vieira-Girão PRN, Rocha IRCB, Costa FHF, Rádis-Baptista G (2012) Differential induction of HSP-70 expression in response to IHHNV in white shrimp Litopenaeus vannamei naturally co-infected with IHHNV and IMNV. Inter Aqua Res 4: 17

12. Schock TB, Duke J, Goodson A, Weldon D, Brunson J, et al. (2013) Evaluation of Pacific white shrimp (Litopenaeus vannamei) health during a superintensive aquaculture growout using NMR-based metabolomics. PLoS One, 8:e59521.

13. Selvam DG, Mujeeb Rahiman KM, Mohamed Hatha AA (2012) An investigation into occasional White Spot Syndrome Virus outbreak in traditional paddy cum prawn fields in India. Scient Wor J, doi: 10.1100/2012/340830.

14. Tumburu L, Shepard EF, Strand AE, Browdy CL (2012) Effects of endosulfan exposure and Taura Syndrome Virus infection on the survival and molting of the marine penaeid shrimp, Litopenaeus vannamei. Chemosphere 86: 912-918

15. Chakraborti J, Bandyapadhyay PK (2011) Seasonal incidence of protozoan parasites of the black tiger shrimp (Penaeus monodon) of Sundarbans, West Bengal, India. J Parasit Dis 35: 61-65

16. Jimenez R, Barniol R, Barniol L, Machuca M (2000) Periodic occurrence of epithelial viral necrosis outbreaks in Penaeus vannamei in Ecuador. Dis Aquat Organ 42: 91-99.

17. Aoki T, Wang HC, Unajak S, Santos MD, Kondo H, et al. (2011) Microarray Analyses of Shrimp Immune Responses. Mar Biotechnol 13: 629-638.

18. Shekhar MS, Kiruthika J, Ponniah AG (2013) Identification and expression analysis of differentially expressed genes from shrimp (Penaeus monodon) in response to low salinity stress. Fish Shell Immun 35: 1957-1968.

19. Li CC, Yeh ST, Chen JC (2010) Innate immunity of the white shrimp Litopenaeus vannamei weakened by the combination of a Vibrio alginolyticus injection and low-salinity stress. Fish Shell Immun 28: 121-127.

20. Vaseeharan B, Ramasamy P, Wesley S G, Chen JC (2013) Influence of acute salinity changes on biochemical, hematological and immune characteristics of Fenneropenaeus indicus during white spot syndrome virus challenge. Microbiol Immunol 57: 463-469.

21. Ramos-Carreño $S$, Valencia-Yáñez $R$, Correa-Sandoval $F$, Ruíz-García $N$ Díaz-Herrera F, et al. (2014) White spot syndrome virus (WSSV) infection in shrimp (Litopenaeus vannamei) exposed to low and high salinity. Archives of Virology 159: 2213-2222. 